\title{
Elemental diet for refractory atopic eczema
}

\author{
J Devlin, T J David, R H J Stanton
}

\begin{abstract}
A total of 37 children with refractory widespread atopic eczema were treated with an antigen avoidance regimen comprising hospitalisation, exclusive feeding with an elemental formula for a median duration of $\mathbf{3 0}$ days, and measures to reduce exposure to pet and dust mite antigens at home. After the initial period of food exclusion, food challenges were performed at intervals of seven days, and the patients followed up for at least 12 months. Ten of the children (27\%) either failed to respond to the regimen or relapsed within 12 months. Improvement in the eczema was seen in $27 / 37(73 \%)$ patients, by discharge from hospital their disease severity score had fallen to a median of $27 \%$ of the pretreatment figure, and only 3/27 required topical corticosteroids. There were no clinical or laboratory findings which could be used to predict the outcome. Drawbacks to the regimen were prolonged hospitalisation (median 70 days), a fall in body weight and serum albumin concentration, and a risk of anaphylactic shock (4/37 cases). A strict antigen avoidance regimen may be associated with improvement of atopic eczema where conventional treatments have failed.
\end{abstract}

A small proportion of children with atopic eczema remain severely handicapped with severe and widespread eczematous skin lesions. This may happen despite the most intensive application of conventional treatment, ${ }^{1}$ such as emollients, topical steroids, antibiotics for infection, bedtime sedating antihistamines, and avoidance of allergic (for example, pets or foods $^{2}$ ) or non-allergic (for example, heat or woollen clothing) triggers that have been identified from the history. In such extreme cases, the traditional additional therapeutic options are unappealing. They comprise the application of potent topical steroids to large areas of skin, with the risk of skin atrophy and growth stunting, the use of systemic steroids, with the risk of growth stunting, cataract, osteonecrosis and other side effects, or doing nothing and leaving the child chronically handicapped and unable fully to engage in normal activities. Recent experimental approaches are no more attractive. Photochemotherapy has been tried in a small number of cases with some success, but problems include severe irritation during treatment requiring systemic steroids, relapse after treatment, and the increased long term risks of skin cancer and cataract formation. ${ }^{34}$ Oral cyclosporin has been used with dramatic benefit in a few adult cases of atopic eczema, ${ }^{5}$ but return of disease after stopping treatment, and risks of renal toxicity and lymphoma production are major drawbacks. Topical cyclosporin appears less effective. ${ }^{6}$ Anecdotal reports of treatment with cytotoxic agents (cyclophosphamide, azathioprine, mustine, thioguanine, and aminopterin) describe temporary benefit, but bone marrow toxicity, lymphoma production, and sterility are deterrents to the use of these agents. Interferon gamma has been tried, with some degree of benefit, ${ }^{7}$ but the temporary nature of the improvement and the need for injections are drawbacks.

Where a case of atopic eczema is refractory to conventional treatment, the question arises as to whether part or all of the disease can be attributed to allergic reactions to items such as food, pets, or dust mites. Accordingly, and only as a last resort, we have in exceptionally difficult cases tried an extreme antigen avoidance regimen, which comprises a prolonged so called elemental diet while in hospital, accompanied by measures to reduce exposure to pet and dust mite antigens upon return home. We report on 37 children with severe atopic eczema who were treated in this way.

Patients and methods

Since 1980, 600 children with atopic eczema, who fulfilled the diagnostic criteria of Hanifin and Rajka, ${ }^{8}$ have been referred to the Department of Child Health at Booth Hall Children's Hospital. In 43 of these the disease was widespread and severely handicapping, the condition had failed to respond to conventional topical treatment ${ }^{1}$ and dietary regimens, ${ }^{2}$ and the patient was considered for an extreme antigen avoidance regimen including an elemental diet in hospital using Vivonex (Tolerex) Standard (available from Norwich Eaton Pharmaceuticals, 17 Eaton Avenue, PO Box 231, Norwich, NY 13815, USA). One family declined this approach, and two children aged 4 and 11 years refused to drink Vivonex so the procedure was abandoned. We present data on the $37 / 40$ patients who have been followed up for 12 months or longer.

ANTIGEN AVOIDANCE MEASURES AT HOME

Removal of all mammalian and avian pets from the home was a prerequisite for treatment and was undertaken in 13 patients. The home was visited by TJD or JD to ensure that rigorous measures (described elsewhere ${ }^{1}$ ) were taken to reduce house dust mite levels in the patient's bedroom. 
PATIENT MONITORING

The percentage of skin surface area affected by eczema and the degree of erythema (graded as mild $=1$, moderate $=2$, severe $=3$ ) were multiplied to give a combined disease severity score. Assessments were made by TJD or JD on admission to hospital, at the end of the period of exclusive feeding with Vivonex, at the time of discharge from hospital, and at follow up visits. Topical corticosteroids were classified according to the British National Formulary ${ }^{9}$ as category IV (mildly potent), category III (moderately potent), category II (potent), or category I (very potent).

Laboratory tests for specific IgE antibodies, radioallergosorbent (RAST) tests, were performed on admission, using a panel of 15 to 30 (depending on availability) common foods and other antigens. During hospitalisation, twice a week measurement was made of the serum proteins, electrolytes, and absolute eosinophil counts, and weekly measurements were made of the serum IgE concentration.

\section{OTHER TREATMENT}

Corticosteroids were discontinued at the time of admission. Simple emollients (usually emulsifying ointment) were applied topically when necessary. Trimeprazine tartrate, an $\mathrm{Hl}$ receptor antagonist, which had been used in a dose of $3 \mathrm{mg} / \mathrm{kg}$ (to a maximum of $60 \mathrm{mg}$ ) by all patients before admission for night sedation, was continued. Because of the poor palatability of unflavoured Vivonex, cyproheptadine, an $\mathrm{Hl}$ receptor antagonist with some appetite stimulant effect, ${ }^{10}$ was also given until food was reintroduced, in a dose of $2 \mathrm{mg}$ twice a day.

\section{DIETARY MANAGEMENT}

All normal food and drink (including water) were excluded, and the child was fed exclusively on unlimited quantities of unflavoured Vivonex. To minimise the possibility of osmotic diarrhoea, patients were started at a low concentration $(6.7 \mathrm{~g} / 100 \mathrm{ml}, 140 \mathrm{mOsm} / \mathrm{kg})$, gradually increasing to isotonicity $(13 \mathrm{~g} / 100 \mathrm{ml}, 280$ $\mathrm{mOsm} / \mathrm{kg}$ ) on the third day. If this did not provoke loose stools, the concentration was increased further to a maximum of $26 \cdot 7 \mathrm{~g} / 100$ $\mathrm{ml}(560 \mathrm{mOsm} / \mathrm{kg})$. The first three patients received Vivonex alone for 7,16 , and 17 days respectively, but this was lengthened to a minimum of four weeks in all subsequent patients. This was partly because it was found that in most patients noticeable improvment only occurred after four to six weeks, and also because an incomplete response made the subsequent interpretation of food challenges much more difficult.

After 28 days of Vivonex given alone, if there was little or no improvement the diet was abandoned, and systemic or topical corticosteroids were used instead. If there was a moderate improvement the period of elemental diet was extended for another one to two weeks. If the eczema had largely resolved, then open food challenges were commenced. Foods to which the patient had a history of adverse reaction, and cows' milk, eggs, wheat, fish, nuts, tomato, citrus fruits, and legumes were deliberately avoided for early challenges. In hospital, each new food was given in quantities of 50 to $200 \mathrm{~g}$ two to four times a day for a period of seven days.

During this time the patient's skin was observed every four hours for deterioration, and other indications of intolerance such as respiratory or gastrointestinal symptoms were noted. The criteria for a positive challenge were (1) a sustained deterioration of eczema (increased scratching and visible worsening of eczematous skin lesions, lasting more than 24 hours), or other adverse reaction (for example, angioedema or asthma) during exposure to the food, and (2) a return to the prechallenge state after the food was withdrawn. If the second criterion was not met, the challenge was not classified as positive or negative, the food was avoided, and a repeat challenge was performed at a later date.

\section{DISCHARGE FROM HOSPITAL AND OUTPATIENT} FOLLOW UP

Patients were discharged from hospital once established on three foods, at which point Vivonex was discontinued. For the first week at home no food challenges were performed, and the child was kept indoors to ensure that the home environment did not provoke eczema. Food challenges were then continued at home and when positive the challenge was repeated at intervals of six to 12 months. All diets were supervised by a paediatric dietitian (RHJS). After discharge from hospital, the nutritional adequacy of the diet ${ }^{11} 12$ was monitored by means of five day diet surveys. ${ }^{13}$ If by three months after discharge the dietary intake of calcium was below the recommended daily amount, ${ }^{14}$ oral calcium supplements were given in the form of tablets containing calcium sodium lactate and calcium phosphate.

\section{Results}

Details of the patient's age, pretreatment severity of eczema, duration of the hospital admission, duration of use of Vivonex, maintenance concentration of Vivonex, and lowest serum albumin are given in table 1 . The patients were followed up for between one and eight years, and table 2 gives details of eczema and asthma severity, treatment, and diet during six years of follow up. Thirty five out of 37 (95\%) patients had a raised (compared with age related normal values) pretreatment serum IgE concentration, median $12500 \mathrm{kU} / \mathrm{l}$ (range 11 to $224000 \mathrm{kU} / \mathrm{l}$ ). During the Vivonex only period there was no correlation between change in disease severity and change in serum IgE concentration. Spearman's rank correlation coefficient $r=0 \cdot 02$. Taking $0.44 \times 10^{9} / 1$ as the upper limit of normal for the absolute eosinophil count, 33/37 patients had a pretreatment eosinophilia.

TREATMENT FAILURE

(a) Non-responders

In four patients (three were girls), the disease 
Table 1 Age of patients, pretreatment disease severity, duration of hospitalisation, strength of Vivonex, and lowest serum albumin concentration

\begin{tabular}{|c|c|c|c|c|c|c|c|c|c|}
\hline \multirow{2}{*}{$\begin{array}{l}\text { Age } \\
\text { (years) }\end{array}$} & & \multicolumn{3}{|c|}{ Pretreatment state of eczema } & \multirow{2}{*}{$\begin{array}{l}\text { Days } \\
\text { in } \\
\text { hospital }\end{array}$} & \multirow{2}{*}{$\begin{array}{l}\text { Days } \\
\text { on } \\
\text { Vivonex } \\
\text { alone }\end{array}$} & \multirow{2}{*}{$\begin{array}{l}\text { Total days } \\
\text { on } \\
\text { Vivonex }\end{array}$} & \multirow{2}{*}{$\begin{array}{l}\text { Maintenance } \\
\text { concentration } \\
\text { of } \\
\text { Vivonex }(\mathrm{g} / \mathrm{l})\end{array}$} & \multirow{2}{*}{$\begin{array}{l}\text { Lowest } \\
\text { serum } \\
\text { albumin } \\
(\mathrm{g} / \mathrm{l})\end{array}$} \\
\hline & & $\begin{array}{l}\text { Surface } \\
\text { area } \\
(\%)\end{array}$ & $\begin{array}{l}\text { Erythema } \\
\text { score* } \\
(\%)\end{array}$ & $\begin{array}{l}\text { Combined } \\
\text { scoret }\end{array}$ & & & & & \\
\hline $\begin{array}{l}\text { Median } \\
\text { Range }\end{array}$ & $\begin{array}{l}3 \cdot 32 \\
0 \cdot 45-13 \cdot 23\end{array}$ & $\begin{array}{l}70 \\
20-96\end{array}$ & $\begin{array}{l}3 \\
2-3\end{array}$ & $\frac{210}{60-288}$ & $\begin{array}{l}72 \\
45-189\end{array}$ & $\stackrel{30}{7-43}$ & $\stackrel{62}{7-124}$ & $\begin{array}{l}16 \cdot 7 \\
13 \cdot 3-26 \cdot 7\end{array}$ & ${ }_{9-32 \ddagger}$ \\
\hline
\end{tabular}

${ }^{*} 1=$ Mild, $2=$ moderate, $3=$ severe.

tCombined score $=$ surface area $\times$ erythema score.

$¥$ Not recorded in 10 patients.

Table 2 Progress of disease severity, treatment, diet, and asthma severity during hospitalisation and follow up

\begin{tabular}{|c|c|c|c|c|c|c|c|c|c|c|c|}
\hline \multirow[t]{2}{*}{ Time } & \multirow{2}{*}{$\begin{array}{l}\text { Stant } \\
\text { Vivonex } \\
(n=37)\end{array}$} & \multirow{2}{*}{$\begin{array}{l}\text { End } \\
\text { Vivonex } \\
(n=37)\end{array}$} & \multirow{2}{*}{$\begin{array}{l}\text { Discharge } \\
\text { home } \\
(n=37)\end{array}$} & \multicolumn{8}{|c|}{ Hospitalisation/follow up } \\
\hline & & & & $\begin{array}{l}6 \text { weeks } \\
(n=37)\end{array}$ & $\begin{array}{l}6 \text { months } \\
(n=37)\end{array}$ & $\begin{array}{l}1 \text { year } \\
(n=37)\end{array}$ & $\begin{array}{l}2 \text { years } \\
(n=31)\end{array}$ & $\begin{array}{l}3 \text { years } \\
(n=25)\end{array}$ & $\begin{array}{l}4 \text { years } \\
(n=16)\end{array}$ & $\begin{array}{l}5 \text { years } \\
(n=12)\end{array}$ & $\begin{array}{l}6 \text { years } \\
(n=9)\end{array}$ \\
\hline $\begin{array}{l}\text { Disease severity } \\
\text { Median } \\
\text { Range }\end{array}$ & ore ratio:* & $\begin{array}{l}0.33 \dagger \\
0.03-1.34\end{array}$ & $\begin{array}{l}0.22 \\
0-0 \cdot 75\end{array}$ & $\begin{array}{l}0 \cdot 24 \\
0 \cdot 01-1 \cdot 27\end{array}$ & $\begin{array}{l}0 \cdot 17 \\
0-1 \cdot 00\end{array}$ & $\begin{array}{l}0 \cdot 07 \\
0-1 \cdot 18\end{array}$ & $\begin{array}{l}0.05 \\
0-0.63\end{array}$ & $\begin{array}{l}0.01 \\
0-0.31\end{array}$ & $\begin{array}{l}0.02 \\
0-0 \cdot 36\end{array}$ & $\begin{array}{l}0 \\
0 \\
0-0.32\end{array}$ & $\begin{array}{l}0 \\
0-0.23\end{array}$ \\
\hline $\begin{array}{l}\text { No (\%) on topic } \\
\text { None } \\
\text { Category IV } \\
\text { Category III+ } \\
\text { Systemic }\end{array}$ & $\begin{array}{c}\text { corticoster } \\
0 \\
17(46) \\
16(43) \\
4(11)\end{array}$ & $\begin{array}{l}\text { oid treatment } \\
\begin{array}{c}36 \\
0 \\
0 \\
1 \\
0\end{array}(3)\end{array}$ & $\begin{aligned} & 27(73) \\
& 4(11) \\
& 3(8) \\
& 3(8)\end{aligned}$ & $\begin{aligned} 27 & (73) \\
4 & (11) \\
3 & (8) \\
3 & (8)\end{aligned}$ & $\begin{aligned} & 22(59) \\
& 4(11) \\
& 7(19) \\
& 4(11)\end{aligned}$ & $\begin{aligned} & 20(54) \\
& 6(16) \\
& 7(19) \\
& 4(11)\end{aligned}$ & $\begin{aligned} 17(55) \\
8(26) \\
3(10) \\
3(10)\end{aligned}$ & $\left\{\begin{aligned} & 16(64) \\
& 7(28) \\
& 1(4) \\
& 1(4)\end{aligned}\right.$ & $\begin{array}{l}11(69) \\
4(25) \\
1(6) \\
0\end{array}$ & $\left\{\begin{array}{l}9(75) \\
3(25) \\
0 \\
0\end{array}\right.$ & $\begin{array}{l}8(89) \\
1(11) \\
0 \\
0\end{array}$ \\
\hline $\begin{array}{l}\text { Diet score:‡ } \\
\text { Median } \\
\text { Range }\end{array}$ & & $\begin{array}{l}7 \\
7\end{array}$ & $\begin{array}{l}7 \\
3-7\end{array}$ & $\begin{array}{l}7 \\
5-7\end{array}$ & $\begin{array}{l}6 \\
1-7\end{array}$ & $\begin{array}{l}6 \\
1-7\end{array}$ & $\begin{array}{l}5 \\
1-7\end{array}$ & $\begin{array}{l}4 \\
1-5\end{array}$ & $\begin{array}{l}3 \\
1-5\end{array}$ & $\begin{array}{l}2 \cdot 5 \\
1-5\end{array}$ & $\begin{array}{l}3 \\
1-5\end{array}$ \\
\hline
\end{tabular}

No (\%) on asthma treatment:

$\begin{array}{lccccccccccc}\text { On any treatment } 19(51) & 19(51) & 20(54) & 21(57) & 23(62) & 25(68) & 22(71) & 19(76) & 10(62) & 9(75) & 7(70) \\ \text { On inhaled steroids } 2(5) & 3(8) & 3(8) & 3(8) & 3(8) & 4(11) & 7(23) & 10(40) & 8(50) & 7(58) & 7(70)\end{array}$

${ }^{*}$ Disease severity score expressed as a fraction of starting disease severity score (surface area $\times$ severity)

tDiet score: $1=$ normal, no exclusions; 2 =excludes one or two foods; $3=$ =xcludes three to five foods; $4=$ excludes six to 10 foods; $5=$ excludes more than 10 foods, includes more than 20 foods.

†Significant improvement, $\mathrm{p}<0 \cdot 001$ (Wilcoxon matched pair signed rank test on actual values).

severity score at the end of the Vivonex only period was the same as, or higher than, the starting score, and three patients were started on systemic corticosteroids.

\section{(b) Late failures}

Late failure was defined as improvement on Vivonex, followed by relapse within 12 months requiring either systemic corticosteroids or category III or II topical corticosteroids to areas other than the hands or feet. Six patients (all boys) showed an early improvement but later deteriorated. Two of these patients, who had previously been receiving systemic corticosteroids, had to recommence treatment with oral prednisolone at six months and three years respectively. The other four patients relapsed to their pretreatment state between six weeks and six months after discharge, and required widespread application of category III or II topical corticosteroids.

These 10 treatment failures were compared with the 27 in whom there was a sustained improvement (table 3 ). No significant difference was found for age, sex, pretreatment disease severity score, previous history of food intolerance, pretreatment eosinophil count, or serum concentration of IgE. The median fall in serum albumin concentration in the four early non-responders was $17 \cdot 5 \mathrm{~g} / \mathrm{l}$. This was significantly greater than the median fall $(7 \mathrm{~g} / \mathrm{l})$ in the 17 patients who responded and in whom it was measured ( $p<0.01$, Wilcoxon rank sum test).
Table 3 Characteristics of patients who improved on Vivonex compared with those who did not improve

\begin{tabular}{lccc}
\hline & $\begin{array}{l}\text { Improved } \\
(n=27)\end{array}$ & $\begin{array}{l}\text { Not improved } \\
(n=10)\end{array}$ & $p$ Value \\
\hline $\begin{array}{l}\text { Age: } \\
\text { Median } \\
\text { Range }\end{array}$ & $\begin{array}{l}3 \cdot 2 \\
0 \cdot 4-13 \cdot 2\end{array}$ & $\begin{array}{l}3 \cdot 5 \\
2 \cdot 3-8 \cdot 7\end{array}$ & $>0 \cdot 1^{*}$ \\
$\begin{array}{l}\text { Sex: } \\
\text { No (\%) of males }\end{array}$ & $14(52)$ & $7(70)$ & $0 \cdot 27 \dagger$ \\
$\begin{array}{l}\text { Pretreatment disease severity score: } \\
\text { Median } \\
\text { Range }\end{array}$ & $\begin{array}{c}210 \\
75-288\end{array}$ & $\begin{array}{c}202 \\
60-285\end{array}$ & $>0 \cdot 1^{*}$
\end{tabular}

No (\%) with previous history of food intolerance:

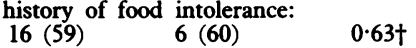

Pretreatment serum IgE concentration (kU/l): $>0 \cdot 1^{*}$ $\begin{array}{lccc}\text { Median } & 12600 & 7400 & >0 \cdot 1^{*} \\ \text { Range } & 87-224000 & 11-164000 & \end{array}$

No (\%) in whom serum IgE concentration fell during Vivonex only period: $\ddagger_{11 / 15}(73) \quad 4 / 9(44) \quad 0 \cdot 16 \dagger$

Pretreatment eosinophil count
Median $\begin{array}{llll}\text { Median } & 0.994 & 1.016 & >0.1 \\ \text { Range } & 0.063-5.302 & 0.550-2.592\end{array}$

No (\%) in whom eosinophil count fell during Vivonex only period: $\S$

$$
11 / 26(46) \quad 7 / 10(70) \quad 0 \cdot 13 t
$$

*Wilcoxon rank sum test; +Fisher's exact test. $\ddagger$ Not recorded in 13 patients.

\$Not recorded in one patient.

The median fall in serum albumin concentration in the six late failure patients $(13.5 \mathrm{~g} / \mathrm{l})$ was also greater than in the patients who responded to treatment, but the difference was not significant $(p>0 \cdot 1)$. 
TREATMENT SUCCESS

In $27 / 37(73 \%)$ patients there was sustained improvement in the eczema. With one exception, where clear improvement was seen within seven days of commencing the elemental diet, the first signs of improvement were not seen for at least one, and more commonly two weeks. It was usually only after four weeks of exclusive feeding on Vivonex, however, that there was substantial improvement in the appearance of the skin lesions. The greatest improvement occurred during the period on Vivonex alone, when the median disease severity score fell to $27 \%$ of the pretreatment score (range 3 to $67 \%$ ). Before treatment, 14/27 (52\%) had been using category IV topical corticosteroids, $12 / 27$ (44\%) had been using category III or II topical corticosteroids, and one patient was receiving oral prednisolone. At the end of the Vivonex alone period, 26/27 (96\%) were using emollients only, and the remaining patient was using a category III topical corticosteroid for small areas of eczema.

This improvement continued in 17/27 (63\%) patients while foods were reintroduced in hospital, and this reduced the median severity score to $18 \%$ of the pretreatment score by the time of discharge from hospital. This further improvement was significant (Wilcoxon matched pair signed rank test on actual values, $p=0 \cdot 01$ ). By discharge from hospital, 24/27 (89\%) patients remained on emollients alone, and two patients commenced category IV topical corticosteroids. Follow up details are given in table 2 .

\section{ADVERSE EVENTS DURING ADMISSION TO} HOSPITAL

Details for weight were not recorded in three early patients. Of the remaining 34, $30(89 \%)$ lost up to $17 \%$ of their body weight while taking Vivonex alone $(<5 \%, 4 ; 5-10 \%, 16 ;>10 \%$, 10). Seven children developed loose stools while on Vivonex, but no patient developed abnormal concentrations of serum electrolytes. After hypoalbuminaemia was noted in one child, the serum albumin was routinely measured. The serum albumin fell in $25 / 27$ patients from a mean (SD) of $30.8(6.0) \mathrm{g} / \mathrm{l}$ on admission to a mean nadir of $21 \cdot 2(7 \cdot 2) \mathrm{g} / \mathrm{l}$. The lowest serum albumin was not significantly related either to the duration of the elemental diet (Spearman's rank correlation coefficient, $r=-0.076, p=0.71)$ or to the concentration of Vivonex used $(r=0.024, p=0.89)$, but was significantly correlated with the combined disease severity score at the start of treatment $(\mathrm{r}=-0.48, \mathrm{p}=0.013)$. Six children obtained forbidden food on one or two occasions, and one child was covertly given normal food by a grandparent for two weeks before this was discovered. None of these seven children were in the 'early failure' group (see below).

FOOD CHALLENGES IN HOSPITAL

A total of 185 challenges were performed in the 37 patients. Twenty had no reactions to a total of 79 challenges, but the other 17 had a total of
40 (median per child 2, range 1 to 7 ) reactions to 13 foods out of a total of 107 challenges.

(a) Reactions occurring within one hour Five children exhibited reactions within an hour of eating a food. One developed anaphylactic shock (with urticaria and bronchoconstriction) within 15 minutes of eating peas (RAST score to peas grade 3), ${ }^{15}$ and another developed anaphylactic shock within 20 minutes of taking a feed of comminuted chicken (RAST score 3 ). ${ }^{16}$ Another child had an itchy erythematous rash, wheezing, and rhinitis within 30 minutes of eating potato (RAST score 0 ). A fourth child had an erythematous rash within an hour of eating corn (RAST score 2). A fifth child developed generalised pruritus and periorbital oedema within minutes of eating lamb (RAST test not performed)

\section{(b) Delayed reactions}

The other 35 reactions consisted of a deterioration in the patient's eczema, with a noticeable increase in itching and erythema, and a return to the prechallenge state after the food had been withdrawn. Seven of these reactions occurred between one and 24 hours of starting the food, four began between 24 and 48 hours after starting a food, and 24 (61\% of all food reactions in hospital) were first noted only two to seven days after introduction of the food. These reactions were to lamb $(n=6)$, corn $(n=6)$, rice $(n=4)$, potato $(n=3)$, Pregestimil (a casein hydrolysate infant milk formula, Bristol-Myers) $(n=3)$, avocado $(n=3)$, carrot $(n=2)$, banana $(n=2)$, chicken $(n=2)$, pea $(n=1)$, pork $(n=1)$, rabbit $(n=1)$, and bean $(n=1)$. The RAST score was known for 17 of these foods and was 0 in 11 positive challenges, 1 in one, 2 in two, and 3 in three.

FOOD CHALLENGES IN THE FIRST I2 MONTHS The results of 853 food challenges were recorded from the end of the elemental diet to one year after discharge in the 37 patients. The median number of challenges per patient was 24 . Two hundred and five $(24 \%)$ of the recorded challenges were positive (median number per patient 5 , range 0 (in one patient) to 19).

\section{REACTION TO PETS, HOUSE DUST MITES, AND} GRASS

Formal challenges were not performed, but after discharge from hospital a clear history of an allergic reaction was noted in 19/37 (51\%) patients: cat $(n=8), \operatorname{dog}(n=17)$, house dust $(n=6)$, hamster $(n=3)$, horse $(n=3)$, pet bird or feathers $(n=3)$, guinea pig $(n=2)$, rabbit $(n=2)$, cow $(n=1)$, and skin contact with grass $(n=13)$.

\section{Discussion}

The aim of this regimen was to achieve a period in hospital of near complete antigen avoidance, and to maximise the avoidance of relevant anti- 
gens during follow up. The chief obstacles were the unpleasant taste of the elemental formula and difficulty in avoidance of inhalant antigens. In fact most children drank the formula after a short period (less than 24 hours) of refusal, and were helped by understanding the aim of the diet. Some children preferred the formula warm, others cold, and two would only take it in the form of ice lollies or crushed ice. Nevertheless, constant scrutiny and encouragement by the nurses and dietitians was required to ensure an adequate intake, and also to prevent other residents on the ward from leaving food or drink accessible to the patient. In one case taps had to be removed in the patient's cubicle to prevent the child drinking water instead of formula, and two children completely refused to drink the formula and in these the regimen was abandoned. Measures to reduce exposure to house dust mites ${ }^{1}$ and pets at home were an integral part of the regimen. The former often entailed considerable expense (for example, replacement of bedroom carpet by cushion flooring; replacement of bed base by non-divan type of bed). The need to remove pets was usually most unpopular, and was sometimes seen by parents to be a greater problem than a period of two to three months of hospitalisation. Most families were helped by a pretreatment visit to another family who had been treated with the regimen, and who were often able to describe exacerbations of eczema after pet exposure and which had only been noted once the eczema had improved while on the regimen. Avoidance of inhalant antigens such as pollens or mould spores was not attempted.

Elemental diets are potentially hazardous. Weight loss despite a theoretically adequate (that is, above the recommended daily amount ${ }^{14}$ ) intake in $30 / 34(89 \%)$ and a reduction in the serum albumin in $25 / 27(93 \%)$ were the most commonly encountered problems. These probably reflect the increased metabolic demands of a child with widespread and long standing skin inflammation. Loose stools occurred in $7 / 37$ (19\%), were attributed to the hypertonicity of Vivonex, and responded to a reduction in concentration. The occurrence of four cases of anaphylactic shock emphasises the potential hazards of food challenges in children with food allergy. This aspect is discussed elsewhere. ${ }^{15-17}$ Thirty patients received hypertonic concentrations of Vivonex. It has been shown in rats that hypertonic feeds may cause increased jejunal permeability to macromolecules $^{18}$ and structural damage to jejunal microvilli. ${ }^{19}$ It is theoretically possible that the former could contribute to a severe hypersensitivity reaction during a food challenge. Such speculation does not have to be invoked to explain our cases of anaphylactic shock, however, which is a well recognised hazard for some children with food allergy. ${ }^{16}$

As far as assessing the benefit of this antigen avoidance regimen, there are three main drawbacks to our methodology. The lack of a control group means that it is not possible to assess how much improvement was due to a placebo effect. It would be desirable, but impractical, to have a control group of patients admitted to hospital for several months but given instead a liquid preparation of normal food, and it would be impossible to disguise the poor flavour of Vivonex. An alternative would be to conduct a randomised study, with half the patients being randomised to a non-treatment arm, and this would be informative for there are no data on the natural history of exceptionally severe atopic eczema. This is important, for in a recent study of a less demanding dietary regimen in a group of less severely affected children with atopic eczema, the outcome at 12 months was the same regardless of response to diet. ${ }^{20}$ It is a common but undocumented observation that atopic eczema sometimes improves swiftly after admission to hospital, whether or not topical corticosteroids have been continued. The usual suggested explanations for this are noncompliance with topical treatment at home, or removal from potential sources of antigens in the home such as pet animals or house dust mites. ${ }^{21}$ The observation that in the present study recovery was rather slow, and continued after discharge, suggests that none of these explanations account for the improvement that occurred in hospital in our patients.

The second methodological drawback is that our patients do not represent a homogeneous category, and were selected solely on the grounds of severity and lack of response to conventional treatment. It is clear that only some of this group are potential responders to antigen avoidance regimens, and it is most unsatisfactory that we were unable to identify any biochemical, immunological, or historical marker that would predict the outcome of the regimen. The difficulty in identifying those who are likely to respond to dietary elimination has been noted before. $^{22}$

The third problem that bedevils all studies of atopic eczema is the lack of an objective method for assessing disease severity. We attempted to use limb movement meters, ${ }^{23}$ but found that their use was associated with a considerable increase in skin damage, children using them as an additional implement while scratching. For scoring disease severity, we combined an estimate of the surface area of affected skin with a subjective assessment of the severity of inflammation. We previously found that this combined score was correlated more closely with biochemical markers of disease severity such as the serum orosomucoid concentration than measures of the surface area alone. ${ }^{24}$ Although this type of scoring system is partly subjective, and does not exclude observer bias, it does eliminate the problem of fluctuation of symptoms such as itching and scratching.

It is generally agreed that double blind, placebo controlled food challenge with tiny quantities of encapsulated freeze dried foods is the best method for confirming adverse reactions to foods. ${ }^{17}$ Nevertheless, there are a number of circumstances where such challenges may give a misleading and incorrect result. ${ }^{15}$ Our challenges were not performed blind, but double blind challenges with normal food portions would be difficult to perform in a child receiving Vivonex alone, where a new food could not be disguised in a 'carrier' food. The alternative 
option of feeding via a nasogastric tube would be unacceptable to most children, and would bypass the oral mucosa, possibly leading to a false negative reaction. ${ }^{25}$ Finally, double blind challenges for three foods, using a seven day period for active challenge, placebo and washout, and repeated three times to reduce the probability of error, ${ }^{26}$ would have extended the period of hospital admission by more than two months. Although we used open challenges, the circumstances were such as to favour a negative challenge, and avoid false positive results. Foods least likely to produce an adverse reaction were deliberately chosen for challenges, so that children could be discharged from hospital and then established on a reasonable diet as quickly as possible. The patients were strongly motivated to tolerate new foods, having been in hospital for a month or more on a highly unpalatable liquid diet. Such circumstances do not exclude bias and overdiagnosis of food allergy, but the lack of double blind methodology cannot explain away the 40 adverse reactions witnessed by nursing and medical staff in hospital and followed by improvement after food withdrawal. The data on outpatient challenges are less secure because they were not supported by constant nursing and medical observation.

Twenty eight of the 40 reactions occurring in hospital in this study did not commence until at least 24 hours after the patient had started to take the food. Delayed reactions resulting in atopic eczema have been repeatedly reported. ${ }^{27-30}$ It is possible that some of these delayed reactions are late phase IgE mediated reactions, ${ }^{12}$ 31-34 attributable to an IgE triggered cascade of infiltration by eosinophils and neutrophils, deposition of eosinophilic major basic protein, release of proinflammatory mediators, and infiltration by monocytes and lymphocytes. ${ }^{35} 36$ However, the lack of correlation between challenges and RAST tests in the present study suggests that most delayed reactions were mediated by mechanisms which do not involve specific IgE antibodies. Finally, it is possible that the long term use of trimeprazine, an $\mathrm{H} 1$ antagonist, may have masked some immediate reactions.

Despite several limitations, the present study has demonstrated that a highly intrusive (minimum hospitalisation two months) and potentially hazardous antigen avoidance regimen was associated with great benefit in some children previously handicapped by refractory, widespread atopic eczema. In the present series, 27 of $37(37 \%)$ such children experienced sustained improvement, although in none did the eczema disappear completely. In four (11\%) patients the treatment failed outright, and in six (16\%) an initial improvement was soon followed by relapse and return to the pretreatment state. It is not possible to estimate how much benefit was due to food or other antigen avoidance. Adverse reactions to pets, house dust, and grass were noted in 19/37 (51\%) patients after discharge from hospital. The slow rate of improvement seen in this study, however, contrasts with the undocumented but often observed rapid improvement seen when some patients go on holiday or are admitted to hospital. This suggests that avoidance of environmental antigens was not the major factor causing improvement in our patients.

Recent paediatric ${ }^{2}$ and dermatological ${ }^{37}$ estimates are that no more than $10 \%$ of children with atopic eczema severe enough to warrant referral to hospital are likely to derive lasting benefit from the use of an elimination diet. In the sole previous study of the use of an elemental diet in the treatment of atopic eczema in childhood, seven children received an elemental feed for only two weeks. ${ }^{38}$ This was followed by six other foods for four weeks. The eczema score improved considerably in six, but in four of these there was little deterioration after returning to a normal diet. In a recent study of 25 children with atopic eczema, either a whey hydrolysate milk formula or Vivonex was given for one to two weeks followed by challenges with foods and food additives. It was noted that in $71 \%$ of patients there was appreciable improvement of the eczema, but only scanty follow up data were available. ${ }^{39}$

This study has two important implications. The first is that there may be a case for trying an elemental diet in a child with severely handicapping atopic eczema which has not responded to simpler diets and conventional topical treatment. The need for a further randomised study is clear. The potential hazards of elemental diets, and the need for very close monitoring, indicate that this is an approach that can only be safely undertaken in hospital, with full paediatric and dietetic support. The second implication is that delayed and probably non-IgE mediated eczematous reactions to foods occur in some children with atopic eczema, and merit more detailed and double blind evaluation.

We thank Dr MR Haeney, department of immunology, Hope Hospital, Salford, for estimations of IgE and RAST testing, and Professor RDH Boyd for his comments. The study was sup ported by the North Western Regional Health Authority (purch ase of limb movement meters). JD was supported by the National Eczema Society.

1 David TJ, Ewing CI. Treatment of atopic eczema in child hood Compr Ther 1988;14:21-6.

2 David TI. Dietary treatment of atopic eczema. Arch Dis Child 1989;64:1506-9.

3 Atherton DJ, Carabott F, Glover MT, Hawk JLM. The role of psoralen chemotherapy (PUVA) in the treatment of severe atopic eczema in adolescence. $\mathrm{Br} \mathcal{f}$ Dermatol 1988;118:791-5.

4 Wolff $\mathrm{K}$. Side-effects of psoralen photochemotherapy (PUVA). Br J Dermatol 1990;122(suppl):117-25.

Ross JS, Camp RDR. Cyclosporin $A$ in atopic dermatitis. $B$ 7 Dermatol 1990;122(suppl):41-5.

6 de Prost Y, Bodemer C, Teillac D. Randomised double-blind placebo-controlled trial of local cyclosporin in atopic dermatitis. Acta Derm Venereol (Stockh) 1989;Suppl144:136-8.

Boguniewicz M, Jaffe HS, Izu A, Sullivan MJ, York D Leung DYM. Recombinant gamma interferon in treatment of patients with atopic dermatitis and elevated IgE levels. Am $\mathcal{Y}$ Med 1990;88:365-70.

8 Hanifin JM, Rajka G. Diagnostic features of atopic dermatitis. Acta Derm Venerol (Stockh) 1980;Suppl 92:44-7.

9 British Medical Association and Royal Pharmaceutical Society of Great Britain. British national formulary. No 19 . London: BMA and the Royal Pharmaceutical Society of Great don: BMA and the

10 Bergen SS. Appetite stimulating properties of cyproheptadine. Am $\mathcal{F}$ Dis Child 1964;108:270-3.

11 David TJ, Waddington E, Stanton RHJ. Nutritional hazards of elimination diets in children with atopic eczema. Arch of elimination diets in childre

12 Devlin J, Stanton RHJ, David TJ. Calcium intake and

cows' milk free diets. Arch Dis Child 1989;64:1183-4.
13 Bassham S, Fletcher LR, Stanton RHJ. Dietary analysis with 
the aid of a microcomputer. Fournal of Micromcomputer Applications 1984;7:279-89.

14 Anonymous. Recommended daily amounts of food energy and nutrients for groups of people in the United Kingdom. London: HMSO, 1981. (Report on Health and Social Subjects, No 15 .

15 David TJ. Hazards of challenge tests in atopic dermatitis. Alleroy 1989;44(suppl 9):101-7.

16 David TJ. Anaphylactic shock during elimination diets for severe atopic eczema. Arch Dis Child 1984;59:983-6.

17 Bock SA, Sampson HA, Atkins FM, et al. Double-blind, placebo-controlled food challenge (DBPCFC) as an office procedure: a manual. $f$ Allergy Clin Immunol 1988;82: p86-97.

18 Cooper M, Teichberg S, Lifshitz F. Alterations in rat jejunal permeability to a macromolecular tracer during a hyperospermeability to a macromolecular tracer

19 Teichberg S, Lifshitz F, Pergolizzi R, Wapnir RA. Response of rat intestine to a hyperosmotic feeding. Pediatr $R e$ 1978;12:720-5.

20 Devlin J, David TJ, Stanton RHJ. Six food diet for childhood atopic dermatitis. Acta Derm Venereol (Stockh) (in press)

21 Beck HI, Korsgaard J. Atopic dermatitis and house dust mites. Br 7 Dermatol 1989;120:245-51.

22 Atherton DJ, Sewell M, Soothill JF, Wells RS, Chilvers CED. A double-blind controlled "rossover trial of an antigen-avoidance diet in atopic eczema. Lancet 1978; 401-3.

23 Summerfield JA, Welch ME. The measurement of itch with ensitive limb movement meters. $\mathrm{Br} f$ Dermato 1980;102:275-80.

24 David TJ, Wells FE, Sharpe TC, Gibbs ACC, Devlin J. Serum levels of trace metals in children with atopic eczema. Br 7 Dermatol 1990;122:485-9.

25 Delohery J, Simmul R, Castle WD, Allen DH. The relationship of inhaled sulfur dioxide reactivity to ingested metabisulphite sensitivity in patients with asthma. Am Rev Respir Dis 1984;130:1027-32.
26 Pearson DJ. Problems with terminology and with study design in food sensitivity. In: Dobbing J, ed. Food intoler ance. London: Baillière Tindall, 1987:1-23.

27 Hill DJ, Ford RPK, Shelton MJ, Hosking CS. A study of 100 infants and young children with cows' milk allergy. Clin Rev Allergy 1984;2:125-42.

28 Hill DJ, Ball G, Hosking CS. Clinical manifestations of cows' milk allergy in childhood. I. Associations with in-vitro cellular immune responses. Clin Allergy 1988;18:469-79.

29 Atherton DJ, Allergy and atopic eczema. Clin Exp Dermato 1981;6:317-25.

30 Hammar H. Provocation with cows' milk and cereals in atopic dermatitis. Acta Derm Venereol (Stockh) 1977;57: atopic der. 159 .

31 Sampson HA. Late-phase response to food in atopic dermatitis. Hospital Practice 1987;22:111-28.

32 Solley GO Gleich GJ, Jordon RE Schroeter AL. The late phase of the immediate wheal and flare skin reaction. Its phase of the immediate wheal and flare skin reaction. Its dependence upon

33 Dolovich J, Hargreave FE, Chalmers R, Shier KJ, Gauldie J Bienenstock J. Late cutaneous allergic responses in isolated IgE-dependent reactions. $\mathcal{f}$ Allergy Clin Immuno 1973;52:38-46.

34 Gleich GJ. The late phase of the immunoglobulin E-mediated reaction: a link between anaphylaxis and common allergic disease? f Allergy Clin Immunol 1982;70:160-9.

35 Sampson HA. The role of food allergy and mediator release in atopic dermatitis. 7 Allergy Clin Immunol 1988;81:635-45.

36 Leiferman KM, Ackerman SJ, Sampson HA, Haugen HS Venenice PY, Gleich GJ. Dermal deposition of eosinophil granule major basic protein in atopic dermatitis: comparison with onchocerciasis. $N$ Engl $尹$ Med 1985;313:285-5.

37 Atherton DJ. Diet and atopic eczema. Clin Allergy 1988;18:215-28.

38 Hill DJ, Lynch BC. Elemental diet in the management of severe eczema in childhood. Clin Allergy 1982;12:313-5.

39 Van Bever HP, Docx M, Stevens WJ. Food and food addi tives in severe atopic dermatitis. Allergy 1989;44:588-94. 